\title{
PRECARIOUS WORK AND SUSTAINABLE DEVELOPMENT
}

This is a pre-print version of the authors. The final text archive is available on Springer at: https://doi.org/10.1007/978-3-319-71058-7 19-1

\author{
Carmen Gago-Cortés ${ }^{1}$, University of A Coruna \\ María Alló ${ }^{2}$ University of A Coruna
}

Definition: Precarious work can be defined, in a general way, as a lack of security in employment that affects multiple dimensions such as the contract period, the labour rights, the wages and the employment relationship.

Synonyms: low-quality work, poor quality work, non-standard work, bad work.

\footnotetext{
${ }^{1}$ Carmen Gago-Cortés, ORCID ID 0000-0002-5670-968X, University of A Coruna, Economic Development and Social Sustainability Research Group (EDaSS), Department of Business, Faculty of Economics and Business, Campus de Elviña s/n, 15071, A Coruña, Spain. E-mail: m.gago@udc.es. Phone number: +34 9811670 00, ext. 2460.

2 María Alló, ORCID ID 0000-0003-1389-7235, University of A Coruna, Jean Monnet Research Group on Competition and Development_C+D Group, Department of Economy, Faculty of Economics and Business, Campus de Elviña s/n, 15071, A Coruña, Spain. E-mail: maria.allo.pazos@udc.es. Phone number: +34 981 1670 00, ext. 4437. Corresponding author.
} 


\section{Introduction}

In last years, we are going through a period of economic and humanitarian crisis. Wars, refugees, hunger, etc. are the real main problems that our society is facing nowadays. The United Nations (2018) has launched an initiative known as the Sustainable Development Goals (SDG), which is composted by a total of seventeen objectives which main goal is to deal and improve the current situation. This initiative was born in 2015 when the worldwide leaders agree a set of objectives to eradicate poverty, to protect the planet and to ensure a sustainable development. Specifically, it was in 2016 when it comes into force until year 2030. Before SDG the United Nations also carried out another initiative known as the Millennium Development Goals (MDG) which was composed by eight objectives. Focusing on the SDG, their main aim is to achieve a sustainable and inclusive development through the consecution of the seventeen goals which are in Figure 1.

Figure 1. Sustainable Development Goals (SDG)

\section{SUSTAINABLE G ALS
DEVELOPMENT G A}
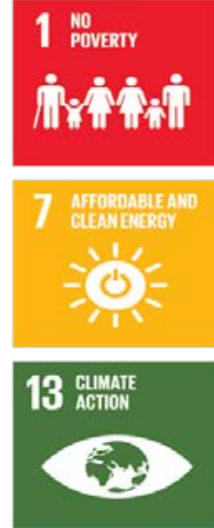
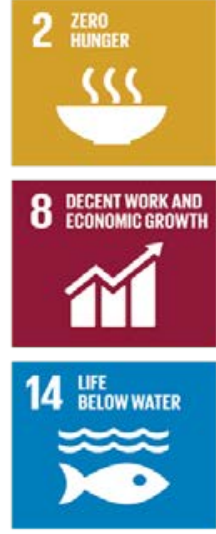
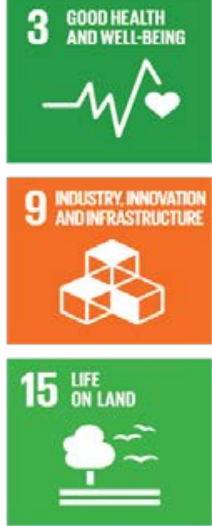
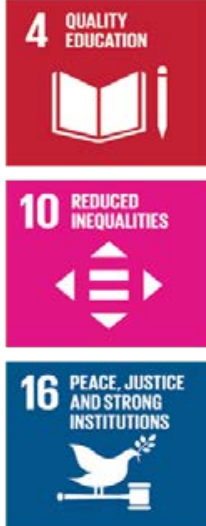
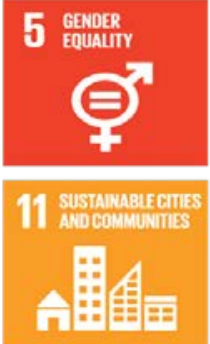

17 Papringspers 83
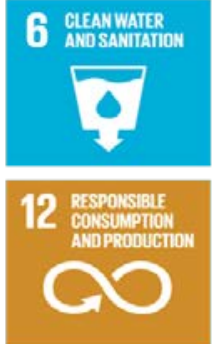

(ㄱ) SUSTAINABLE GEMEN

Source: United Nations (2018). 
This chapter is focused on the analysis of precarious work in Europe. The International Labour Office (2011b) explains as the concept "precarious work" is challenging to define precisely due to the differences between countries which have different regulations and social structures. Blustein et al. (2016) explain as based on Benach et al. (2014) precarious work is composed by four elements: insecurity in terms of employment, vulnerability (lack of power to exercise rights), the level of protection and the level of income.

The International Labour Office (2011b) highlights that precarious work "it is usually defined by uncertainty as to the duration of employment, multiple possible employers or a disguised or ambiguous employment relationship, a lack of access to social protection and benefits usually associated with employment, low pay, and substantial legal and practical obstacles to joining a trade union and bargaining collectively". Thus, according to this organization, the main characteristics are:

- Workers on temporary contracts with variable durations directly employed or hired through an agency.

- Complexities identifying the employer.

- Insufficient or even a total absence of trade union rights.

Broughton et al. (2016) have also published a report where the starting point for the analysis of the precarious work is based on the conceptual framework elaborated by Olsthoorn (2014). In this, three main components are highlighted: the first, is the lower level of secure in employment (work obtained through a temporary agency, short time contracts, etc.); the second is the fact that rights are vulnerable (for example, lower 
economic subsidies) and the third, is related with the vulnerability of the work (for example, lower incomes) (Figure 2).

Figure 2. Main components of precarious work

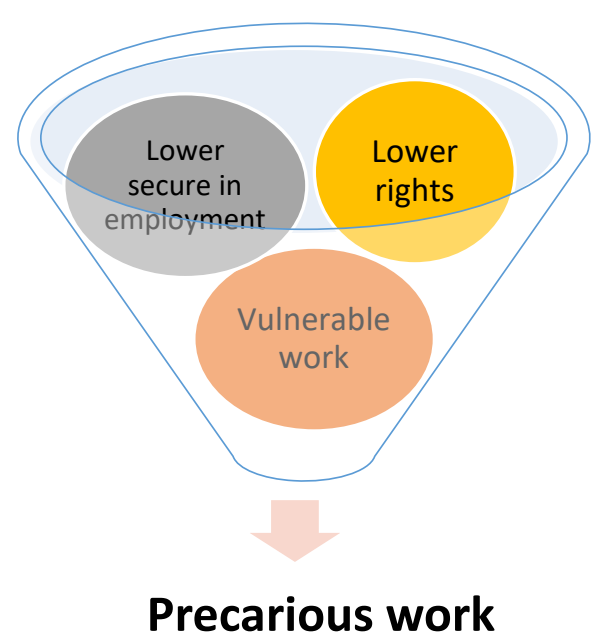

Source: Elaborated from Broughton (2016) and Olsthoorn (2014).

In terms of contractual agreements, the limited duration of the contract (fixed-term, short-term, temporary, seasonal, day-labour or casual labour) and the nature of the employment relationship (triangular and disguised employment relationships, bogus self-employment, subcontracting and agency contracts) are the main characteristics of precarious work.

On the basis of these contributions, a general definition of precarious work can be shown. It can be seen as a lack of security in employment that affects multiple dimensions such as the contract period, the labour rights, the wages and the employment relationship. 
After this short review of the definition of precarious work, five different levels arise as important issues that should be analysed when dealing with this kind of employment according to Campbell and Price (2016):

i. Precariousness in employment. This is a multi-dimensional concept related to specific features of job which trigger insecurity; such as, a weak regulatory protection, low wages and low levels of control over wages, hours or working conditions from the perspective of employees.

ii. Precarious work. It is referred to those jobs that accumulate several dimensions of precariousness, such as non-standard jobs or the so-called "bad jobs".

iii. Precarious workers. It is making reference to those individuals with precarious works, affected by the consequences of precariousness. Examples: a recent graduate doing an unpaid 'internship' at an accounting firm, a single mother trying to achieve an adequate income with part-time contract cleaning jobs, a recent migrant working long weekly hours as a kitchenhand, a blue-collar process worker deployed by a labour hire company and a young academic trying to establish a career through sessional teaching.

iv. Precariat. This is linked with the group of precarious workers which are an emerging class, due to the increase of people in this situation.

v. Precarity. This concept describes a general condition of social life, associated with the uncertainty and instability that suffer the precarious workers. It can be extending to other domains such as housing, welfare provision and 
personal relationships. The hyper-precarity relates to severe forms of labour exploitation suffered, for example, by migrant workers.

Taking into account this context, the main objective of this chapter is to analyse each one of these levels in order to obtain some conclusions that could shed light in the design of better future policies in terms of the SDG. Specially, considering that one of the SDG is related with the promotion of decent work.

The rest of the chapter is organized as follows: Section 2 deals with the question of the precariousness in employment. Section 3 analyses the precarious work and Section 4 the precarious workers. In addition, Section 5 studies the precariat while the Section 6 is focused on precarity. This chapter ends with Section 7 where some important conclusions are discussed.

\section{Precariousness in employment}

Campbell and Price (2016) explain that four dimensions of precariousness in employment can be identified:

- Lack of regulatory protection. Example: statutory legislation (occupational health and safety, workers' compensation and the National Employment Standards) and award regulation, underpinned by the provisions of the common law and supplemented for some employees by collective bargaining agreements.

- Low wages. Example: the employer noncompliance causes hourly rates may fall below even the low rates specified in awards and agreements. For many part- 
time employees, low hourly rates are compounded by short working hours and variable schedules, producing very low and fluctuating weekly pay.

- High employment insecurity. Example: short job tenure and high turnover (parttime job unstable and short-term; uncertainty about employment; unfair dismissal; low access to formal training).

- Low levels of employee control over wages, hours and working conditions. Example: when employer demands for 'flexible scheduling'.

Considering these dimensions, it is important to review the role of labour regulation in precariousness in employment. The labour market situation has developed substantially in last decades. However, the legislative frameworks failed to follow this development, allowing a substantial increment in precarious work arrangements (International Labour Organization 2011b). Both, national and international labour regulations have weaknesses, omissions and gaps. Some specific categories, such as agricultural and domestic workers, are often excluded from the protection of labour legislation. In other cases, the use of temporary and subcontracted labour is not sufficiently limited. Moreover, access to trade union rights is limited, due to the practice of hiring temporary and subcontracted workers, and due the legal limitation of workers to join the trade union of their choosing or to be a part of a specific bargaining unit.

Analysing the legal factor at national level, International Labour Office (2011b) suggests that one of the law factors that can contribute to the expansion of precarious work is the type of work relationship. Some examples of precarity within an employment relationship are identified below. 
- Temporary work. Temporary workers are traditionally less protected than permanent workers. At this regard, there are countries that impose further restrictions to temporary contracts than others. If governments do not limit the rotational use of temporary contracts, employers have de possibility of hire workers on temporary contracts and lay off them before they have access to certain rights. Therefore, it is necessary that countries regulate the labour market to limit the use of temporary workers. These are some ways:

- Imposing specific reasons or circumstances for hire temporary workers.

- Limiting the proportion of these workers that an employer can hire.

- Prohibiting the use of temporary workers in given sectors.

- Limiting the duration or number of temporary assignments for a given worker.

- Low income. Countries with a wide low pay sector generally have neither comprehensive collective bargaining coverage nor statutory minimum wages. This situation is becoming noticeably worse during periods of high unemployment.

- Weak labour regulatory. Weak enforcement of labour law has serious consequences for workers. Even they are protected, they can feel precarious. This situation comes most often in governments that separate the regulation, the implementation and the labour law enforcement in different ministries. 
From an international perspective, there are international labour standards that seek to protect all workers. Conventions and recommendations adopted by the International Labour Conference are of general application, unless otherwise specified. The International Labour Organization emphasizes the freedom of association, the right to collective bargaining, non-discrimination in occupation and employment, equal pay for men and women workers, the abolition of forced labour, and the elimination of child labour.

Besides the role of legal factors, it is also necessary consider the role of economic drives of precarious work as it has also been remarked by the International Labour Office (2011b). In this sense, it is crucial to consider multiple combinations of several factors, such as: the abuse of dominant economic position, the liberalisation of the economy or the increasing global mobility in the markets (in addition to mentioned before, weak protective labour laws, leading by lobbies and some policies guided by the belief in the efficiency of free markets). Thus, in the past few years, most societies have seen an improvement in its economy. The growth in Africa, post-Communist countries, and Latin America has led to a convergence process of the Gross Domestic Product (GDP) on an international level since 2001 (Milanovic 2012). However, the wages and salaries do not have followed the same rhythm (International Labour Organization 2011b).

The standard employment relationship in industrialized countries was based on labour rights, social security, rising wages and collective representation. This standard has contributed to the establishment of a broad middle class and to the upward social mobility. Welfare state provisions and collective bargaining have been achieved the 
same time. Nevertheless, they are now in risk. With the advent of globalisation, the trend of the long post war period was reversed. Employers have started to use cheap labour in order to cut costs and maximize profits. In addition, they are able to hire labour on increasingly less secure contracts within formal enterprises. A divide et impera strategy has been applied (and is being) to undermine the standard employment relationship. In this regard, precarious work is the result of a change of the rules of the game. Currently, with the global capital mobility and the global sourcing options, it is easier for companies relocate their operations to areas with cheaper labour or, alternatively, outsource them, which has caused a job contraction. New information and communication technology advancements, together with the falling transport costs, are contributing in this process.

The theory of unemployment entrapment in neo-liberal economics emphasizes that acute economic deprivation is an important stimulus for a more intense search for employment and for greater flexibility when accepting a job (Gallie et al. 2003). From this neo-liberal perspective, precarious work is the solution to the job contraction. To achieve full-employment it is necessary deregulate labour markets and make work "more flexible". But this neo-liberal doctrine need a government that make the social transfers conditional on accepting any kind of work, facilitating low-pay and precarious work. Therefore, this type of employment policies led to an increase in working poor. Other factors to take into account in creating the precariat are laws that allow easy layoffs, the exclusion of vulnerable groups like youth, women or the elderly from employment protection, and the simultaneous promotion of agency work and reliance on temporary workers. 
As a result, the employment market created over the last decades is working outside control and without an appropriate structure. This supposes a big challenge for policy makers, entrepreneurs, trade unions and other social actors. Traditionally, the responsibility was shared between employer and employee within the framework of labour and social rights. Currently, the unprotected employee bears the burden, resulting in precarity. According to the International Labour Office (2011b), to stop this trend, it is necessary to implement sustainable labour policies that allow secure jobs, which provide decent wages and working hours that are compatible with family life.

\section{Precarious work}

Which conditions are related with precarious jobs? As it has been mentioned before, the International Labour Office (2011b) mentions the following:

- Low wage.

- Poor protection from termination of employment.

- Lack of access to social protection and benefits usually associated with full-time standard employment.

- Lack of or limited access of workers to exercise their rights at work.

There is no perfect correlation between specific forms of employment and precarious work. While casual and external forms of work are growing, the growing of precarious work may be affected by many factors in addition to this. However, there are certain forms of work that have a high correlation with the growth of precarity, such as temporary employment, particularly fixed-term contracts, and temporary agency work (International Labour Organization 2011b). 
What has been the evolution over time of precarious work? Focusing on the temporary forms of employment, they are increasing alarmingly. Figure 3 shows as since 80 's there is a trend to increase the percentage of temporary workers both in European Union (EU) and in the OECD (from 8-9\% to 12-14\%). This, trend is increasing until 2006-2007 and after this period a slight decrease is observed. It is surprisingly that nowadays the percentage of temporary working has no suffered important decreases. In addition, it is also important to emphasize that the economic crisis does not seem to have had importance in terms of temporal contracts.

The problem is moving towards an employment arena in which employers only provide a permanent work to core workers, while all other employees have no security, low wages, poor benefits, and a miniscule chance of professional advancement (International Labour Organization 2011b).

Figure 3. The prevalence of temporary work in OECD and European countries, 1980--2017.

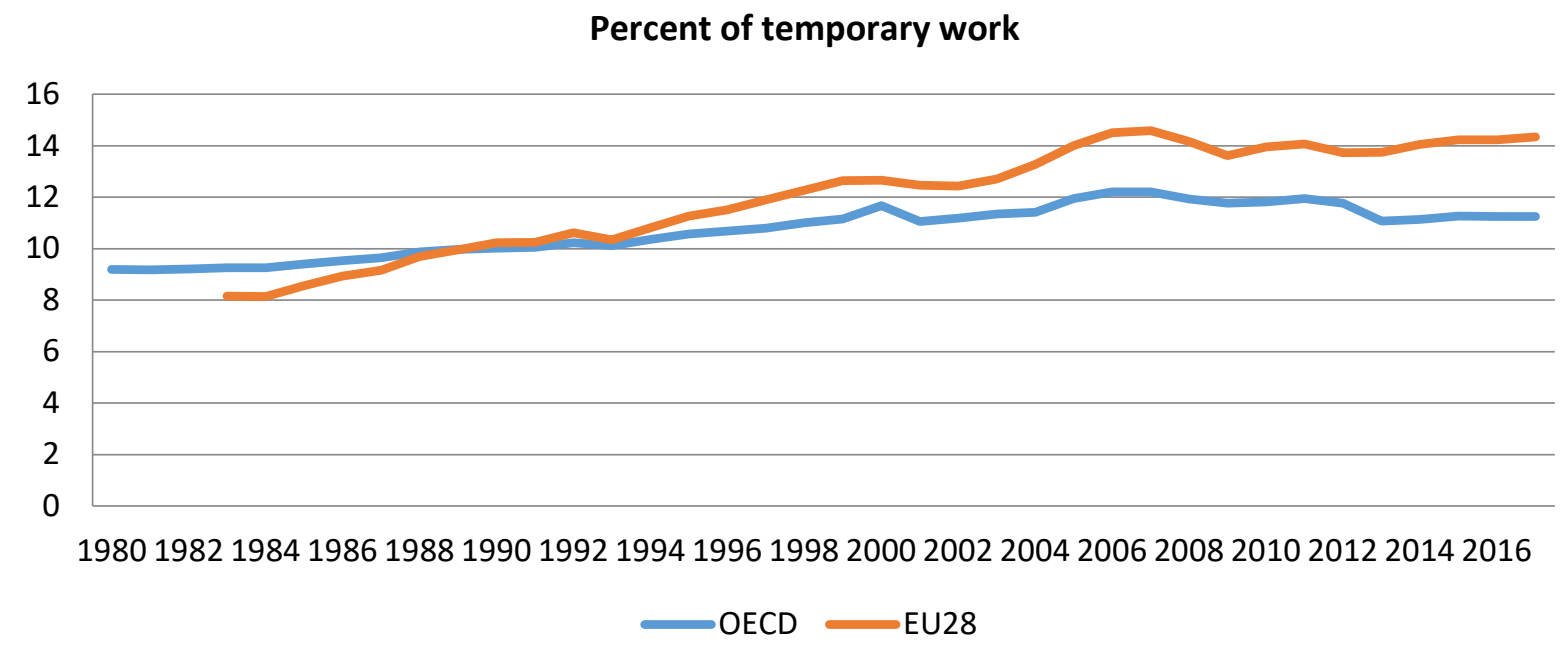

Source: OECD (2018) 
When talking about temporary employments (one of the type of employment over the category of precarious work), it is crucial to consider whether this work is chosen voluntarily or on the contrary whether it is an involuntary situation. Table 1 shows as the percentage of employees that could not find a permanent job in the EU has been increasing over time with a $4.6 \%$ in year 2002 and a $7.8 \%$ in 2017 . Once again, the past economic crisis seems not to be behind these numbers because this increase took place in year 2006. Another important and worrying issue is the percentage of employees with temporary jobs but because they could not find a better job. In this case the trend is the same, in year 2002 around the $37.3 \%$ of the population in the EU was in this situation while in year 2007 the percentage is about $53.9 \%$. This means than more than the half of individuals with temporary contracts are in this situation because they are not able to find better jobs. Thus, the increase was preferably involuntary. The employees must choose this option because no better work is available. 
Table 1. Temporary involuntary jobs in EU, 2002-2017.

\begin{tabular}{|c|c|c|}
\hline EU (current composition) & $\begin{array}{c}\text { Percentage of } \\
\text { employees that could } \\
\text { not find a permanent } \\
\text { job (from } 15 \text { to } 64 \\
\text { years) }\end{array}$ & $\begin{array}{c}\text { Percentage of } \\
\text { employees with a } \\
\text { temporary job that } \\
\text { could not find a } \\
\text { permanent job (from } \\
15 \text { to } 64 \text { years) }\end{array}$ \\
\hline 2002 & 4.6 & 37.3 \\
\hline 2003 & 5.7 & 45.2 \\
\hline 2004 & 6.3 & 48.3 \\
\hline 2005 & 4.8 & 34.1 \\
\hline 2006 & 7.5 & 52.7 \\
\hline 2007 & 7.5 & 51.8 \\
\hline 2008 & 7.2 & 51.8 \\
\hline 2009 & 7.0 & 52.5 \\
\hline 2010 & 7.5 & 54.4 \\
\hline 2011 & 7.4 & 53.2 \\
\hline 2012 & 7.3 & 53.7 \\
\hline 2013 & 7.3 & 54.2 \\
\hline 2014 & 7.6 & 54.9 \\
\hline 2015 & 7.7 & 54.9 \\
\hline 2016 & 7.8 & 55.0 \\
\hline 2017 & 7.8 & 53.9 \\
\hline
\end{tabular}

Source: Eurostat (2018b)

At this point, it is important to note that according to data from the Eurofound (2017), the workers with permanent contracts report more favourable job quality, in general, than workers on temporary contracts. Although the number of temporary involuntary jobs seems not to be affected by the financial and economic crisis of 2008 , during these years it was easier for companies adjust the number of temporary workers and their hours than the number of workers with permanent contracts (Vandekerckhove et al. 2012).

In a country-by-country analysis conducted by the International Labour Office (2011b), Western Continental Europe countries have increased the temporary forms of employment ranging from about 3\% for Austria, Belgium, Luxembourg and Germany to 
$16 \%$ for Spain, with Portugal, France, Italy, the Netherlands standing between $5-9 \%$. Scandinavian countries experienced stable or slightly declining rates over that period. Central European countries reported increases over the period. Greece and Turkey have a declining trend, having started at around $20 \%$ in the 1980 s, with shares hovering around 13\% in 2007.

In order to analyse the evolution of precarious work in the strictest sense, Eurostat (2018a) provides the percentage of workers that are in this situation since year 2002 to year 2017. Thus, in 2002 around $1.6 \%$ of workers were under a precarious situation while in year 2005 this percentage increases to $2.3 \%$ and this number is maintained until 2017. Analysing the geographical differences nowadays (year 2017), Croatia and Montenegro have the higher rates of precarious work in the EU (over 7\%), followed by Turkey (6.4\%) and Slovenia, France and Spain (about 5\%).

Attending to differences between economic sectors, Table 2 shows the data provided by Eurostat. It highlights as the "Agriculture, forestry and fishing" have the higher percentages of precarious work in the EU. 
Table 2. Percentage of precarious work by economic sectors.

\begin{tabular}{|c|c|c|c|c|c|c|c|c|c|c|}
\hline & 2008 & 2009 & 2010 & 2011 & 2012 & 2013 & 2014 & 2015 & 2016 & 2017 \\
\hline $\begin{array}{l}\text { Agriculture, forestry and } \\
\text { fishing }\end{array}$ & 6.9 & 7.6 & 7.3 & 8.2 & 8.5 & 8.6 & 8.3 & 8.6 & 8.1 & 7.9 \\
\hline $\begin{array}{l}\text { Industry and } \\
\text { construction }\end{array}$ & 2.1 & 1.9 & 2.3 & 2.4 & 2.2 & 2.2 & 2.3 & 2.4 & 2.4 & 2.4 \\
\hline $\begin{array}{l}\text { Wholesale and retail } \\
\text { trade, transport, } \\
\text { accomodation and food } \\
\text { service activities }\end{array}$ & 2.6 & 2.3 & 2.5 & 2.7 & 2.6 & 2.6 & 2.7 & 2.8 & 2.9 & 3.0 \\
\hline $\begin{array}{l}\text { Information and } \\
\text { communication; } \\
\text { financial and insurance } \\
\text { activities; real estate } \\
\text { activities; professional, } \\
\text { scientific and technical } \\
\text { activities; administrative } \\
\text { and support service } \\
\text { activities }\end{array}$ & 2.1 & 2.0 & 2.0 & 2.1 & 2.1 & 2.0 & 2.0 & 2.0 & 2.0 & 1.9 \\
\hline $\begin{array}{l}\text { Public administration, } \\
\text { defence, education, } \\
\text { human health and social } \\
\text { work activities; arts, } \\
\text { entertainment and } \\
\text { recreation; activities of } \\
\text { extraterritorial } \\
\text { organisations and } \\
\text { bodies }\end{array}$ & 1.6 & 1.6 & 1.6 & 1.6 & 1.6 & 1.5 & 1.5 & 1.6 & 1.6 & 1.5 \\
\hline $\begin{array}{l}\text { Other service activities, } \\
\text { activities of households } \\
\text { as employers }\end{array}$ & 2.6 & 2.5 & 2.6 & 2.8 & 2.7 & 2.5 & 2.6 & 2.5 & 2.6 & 2.7 \\
\hline No response & 6.3 & 4.2 & 4.1 & 4.8 & 4.2 & 5.4 & 6.3 & 6.5 & 5.6 & 5.7 \\
\hline
\end{tabular}

Source: Eurostat (2018a)

\section{Precarious workers}

The recent past economic crisis has resulted in an increasingly social unrest, and people protest in cities because of their unsustainable conditions of work and life (International Labour Organization 2011b). Precarious work seems to be normalized, and this affects to the long-term decisions of workers. Plans such as get married, have children, or purchase homes become impossible, contributing to the severe demographic crisis of several countries in Europe. Young generation is especially affected. The number of young workers with temporary contracts or who are employed through temporary 
agencies has increased along with the overall use of flexible contracts. According to Eurofound (2017) data "the proportion of younger workers in temporary contractual arrangements (19\%) or in 'other or no contract' (13\%) is much higher than that of the other age groups."

Another point to have in mind when focusing on the social aspect is that part-time jobs may be precarious, but not in the same way for all people. For example, it's not the same a student that combine school and a part-time job, as a head of household that depends of this employment to keep the family afloat. The impact in their lives is especially relevant in the presence of social conditions, such as the dependence of full-time workers on the wage for their livelihood, family relations, social norms, education and the welfare regimes (Campbell and Price 2016). Social relations outside the workplace and the action of institutions may imply different effects of workers. The welfare state payments in order to reduce the risk of poverty could be considered a positive effect. On the contrary, an example of a negative effect could be immigration rules that positions workers in a precarious status.

\section{Precariat}

International labour standards seek to protect all workers. At this regard, the conventions and recommendations adopted by the International Labour Conference are of general application, unless otherwise specified. Nevertheless, it should be mentioned that many specific labour rights are conferred based on the existence of an employment relationship. To that end, the ILO Employment Relationship Recommendation (No. 198) 
of (2006) emerges to combat disguised employment relationships and allow employees to have a protection level. The recommendation, although it is not binding, proposes that national regulatory authorities "take particular account in national policy to ensure effective protection to workers especially affected by the uncertainty as to the existence of an employment relationship, including women workers, as well as the most vulnerable workers, young workers, older workers, workers in the informal economy, migrant workers and workers with disabilities".

As noted in this recommendation, there are some categories of vulnerable workers that suffer more frequently the precarious working conditions. For example: involuntary part-time (women workers), temporary and “McDonalds jobs" (young workers), low-pay work (youth, disabled workers), seasonal or domestic works (migrant and women workers). For this reason, the ILO has extended labour protections through specific standards for vulnerable workers. These are some Conventions developed for this purpose:

- The Migration for Employment Convention (1949) (No. 97) and the Migrant Workers Convention (International Labour Organization 1975) (No. 143).

- The Workers with Family Responsibilities Convention (1981) (No. 156).

- The Vocational Rehabilitation and Employment (Disabled Persons) Convention (1983) (No. 159).

- The Maternity Protection Convention (2000) (No. 183).

- The Home Work Convention (1996) (No. 177).

- The Domestic Workers Convention (2011a) (No. 189). 
Regarding agency workers, Convention No. 181 (1997) favours their access to their fundamental rights at work improving their working conditions, although does not limit the use of this type of workers.

The Minimum Wage Fixing Convention (1970) (No. 131) provides protection to employees with wages below an adequate minimum. This standard obliges countries to establish a minimum wage that addresses "the needs of workers and their families, taking into account the general level of wages in the country, the cost of living, social security benefits, and the relative living standards of other social groups".

The Part-Time Work Convention (1994) (No. 175) seeks for part-time workers receive the same protection as full-time workers. Part-time employees should benefit from conditions equivalent regarding maternity protection, end of contract, paid annual leave and paid bank holidays, and sick leave. This Convention also seeks to protect workers against involuntary part-time, promoting initiatives aimed at preventing workers "from being trapped in part-time employment".

Table 3 presents the percentage of temporary employees by age and as it can be seen younger people are the most affected by this type of employment. Therefore, during the last year and according to the data of Eurostat (2018c) it seems that younger people are becoming the new precariat class. 
Table 3. Temporary employees as a percentage of the total number of employees by age (\%)

\begin{tabular}{lrrrrrrrrrr}
\hline EU & & & & & & & & & & \\
current composition) & $2015 Q 4$ & $2016 Q 1$ & 2016Q2 & 2016Q3 & 2016Q4 & 2017Q1 & 2017Q2 & $2017 Q 3$ & $2017 Q 4$ & $2018 Q 1$ \\
\hline From 15 to 19 years & 56.9 & 56.2 & 57.3 & 60.2 & 58.5 & 57.3 & 58.4 & 61.9 & 58.6 & 57.1 \\
From 15 to 24 years & 43.1 & 42.4 & 43.9 & 44.9 & 43.7 & 42.9 & 44.1 & 45.8 & 44.0 & 42.8 \\
From 15 to 29 years & 32.1 & 31.3 & 32.6 & 33.3 & 32.2 & 31.4 & 32.6 & 33.6 & 32.3 & 31.6 \\
From 15 to 39 years & 21.7 & 21.0 & 22.0 & 22.4 & 21.9 & 21.2 & 22.1 & 22.7 & 21.9 & 21.4 \\
From 15 to 59 & 14.5 & 14.1 & 14.7 & 15.0 & 14.6 & 14.2 & 14.9 & 15.2 & 14.8 & 14.3 \\
From 15 to 64 & 14.1 & 13.7 & 14.4 & 14.6 & 14.3 & 13.8 & 14.4 & 14.8 & 14.3 & 13.9 \\
From 15 to 74 & 14.2 & 13.7 & 14.4 & 14.6 & 14.3 & 13.8 & 14.5 & 14.8 & 14.3 & 13.9 \\
\hline
\end{tabular}

Source: Eurostat (2018c)

\section{Precarity}

Both precariousness and precarious work are related to labour insecurity. The employers are taking advantage of the weak labour regulation to reduce labour costs and the quality of employment. And the consequences for precarious workers may range from a decrease of physical, mental well-being to the decline of other aspects of social life linked to paid work (Campbell and Price 2016). Paid work is relevant for the quality of life because of the income but also because it provides identity to people and opportunities to socialize with others (Stiglitz et al. 2009).

The new economy approaches focus the attention on those objective characteristics on which people's quality of life depends. These characteristics include the personal activities, and decent work is within these. It is necessary pointing to the high costs of involuntary unemployment for people's quality of life. In addition to income, nonpecuniary effects of job instability (sadness, stress and pain) among the unemployed and of fears and anxieties generated by unemployment in the rest of society must be mentioned (Stiglitz et al. 2009). 
Most modern societies are faced with an accelerated urbanization process. Population groups of different origins and cultures move to cities in search of better opportunities. However, in many cases, they are forced to accept those jobs that nobody wants. According to Peter Drucker, the problems of social minorities originate in the lack of a position and a social function. He argues that the way to integrate into the group is through the property or the contract. In this way, employment is one of the mechanisms to obtain a position and a social function (Stein 2008).

Between these population groups are the migrant workers. These individuals suffer a considerable job insecurity: they have higher unemployment rates and when in employment, they are frequently segregated into low-paid, unskilled and precarious employment. Table 4 shows data available regarding the lack of opportunities for these people in access labour market in EU countries. Fewer opportunities for training, language barriers, limited access to the public sector and to managerial positions, ethnic prejudices, legal barriers, discrimination by colleagues or educational qualifications are some factors that contribute to the hyper-precarity of migrant workers. Finally, it is important to remark that due to the crucial role played by migrant workers in the economic growth of countries, Eurofound (2007) recommend paying more attention to their employment and working conditions. 
Table 4: Labour market barriers of migrant workers in European countries.

\begin{tabular}{|c|c|}
\hline Austria & Fewer opportunities for training; language barriers \\
\hline Belgium & Limited access to the public sector; ethnic prejudices \\
\hline Cyprus & Language and legal barriers \\
\hline Czech Republic & Discrimination by colleagues \\
\hline Germany & Educational qualifications \\
\hline Denmark & Educational qualifications \\
\hline Estonia & Limited access to the public sector and to managerial positions \\
\hline Spain & $\begin{array}{l}\text { Discrimination by employers; bureaucratic barriers to full labour } \\
\text { market integration }\end{array}$ \\
\hline Finland & Ethnic prejudices; educational qualifications; language barriers \\
\hline France & $\begin{array}{l}\text { Educational qualifications and discrimination related to ethnic } \\
\text { prejudices }\end{array}$ \\
\hline Netherlands & Ethnic prejudices \\
\hline Lithuania & Language barriers \\
\hline Luxembourg & Ethnic prejudices \\
\hline Malta & Language barriers, ethnic prejudices \\
\hline Sweden & Fewer opportunities for training; discrimination by employers \\
\hline Slovenia & Educational qualifications \\
\hline
\end{tabular}

Source: Adapted from Eurofound (2007). National contributions of European Observatory on Working Conditions (EWCO) correspondents 2006. 


\section{Conclusions}

Different countries in the world present the same characteristics: wage employment is increasing, but with more insecurity for the employees. In this situation, labour protection laws play a crucial role. In countries with absence of permanent forms of contract, the employers can abuse of workers' rights because the employees main goal is the renewal of contract. The fear leads to workers not to join trade unions, increasing their vulnerability to precarious work arrangements.

It is necessary to include the labour market policies in a broader set of measures, which must be consistent and complementary. Even under the current globalization regime, it is possible that countries improve social economic outcomes with this type of policies.

According to ILO (2011b), these are some main economic and social measures to take into account preventing precarious work:

- Full-employment as the main goal of economic policy. Monetary, fiscal and industrial policies must converge to ensure quality employment for all. At this regard, the International Labour Organization (ILO) has established the Employment Policy Convention (1964) (No. 122). Article 1 indicates that "with a view to stimulating economic growth and development, raising levels of living, meeting manpower requirements and overcoming unemployment and underemployment, each Member shall declare and pursue, as a major goal, an active policy designed to promote full, productive and freely chosen employment". 
- Reduce financial market volatility. Global capital mobility, off-balance-sheet banking, opaque risk allocation through derivatives, speculative exchange rate determination and regulations are forcing institutional investors to follow assessments of rating agencies. The financial sector increases in this way the profit and power, reducing the productive investment and imposing unsustainable profit margins on companies. Companies reach this goal through redistribution from wages, taxes or consumer prices. The following are policy measures that could reduce financial market volatility: a financial transaction tax, separating saving banks and investment banking, higher reserve requirements, closure of offshore banking, and downsizing financial institutions that are too huge.

- Welfare state provisions and active labour market policies. The chasm between rich and poor can be bridged if governments strengthen progressive tax structures. Also, the public investment is key to maintain employment levels and to reach socioeconomic equity and sustainability. High standards of employment should be a government priority in order to improve working conditions and pay. Provide universal access to education, health and care facilities as well as longterm employment opportunities is also an important issue.

- Collective bargaining for favouring wage growth. Governments must to ensure a living minimum wage and social security, including universal access to unemployment benefits and public work opportunities. In addition, governments have to encourage the application of collective bargaining to avoid the abuse of power by employers. 
- Limiting the use of agency work and temporary workers. The primary aim is no longer to increase temporary or agency work above a reasonable level, about five per cent of their workforce. Temporary contracts must be used only during peak periods of labour demand and transform automatically to a permanent contract after a three-month probation period, if they are not related to a special task or project. The higher risks of work, accidents, and unemployment of temporary and agency workers should be reflected in higher social security contributions for the companies. 


\section{References}

Benach J, Vives A, Amable M et al (2014) Precarious employment: understanding an emerging social determinant of health. Annu Rev Public Health 35.

Blustein DL, Olle C, Connors-Kellgren A et al (2016) Decent work: A psychological perspective. Frontiers in psychology 7:407.

Broughton A, Green M, Rickard C et al (2016) Precarious employment in Europe. Employment and Social Affairs).Brussels: European Parliament.Directorate-General.

Campbell I, Price R (2016) Precarious work and precarious workers: Towards an improved conceptualisation. The Economic and Labour Relations Review 27(3):314-332.

doi:10.1177/1035304616652074.

Eurofound (2007) Employment and working conditions of migrant workers.

Eurofound (2017) Sixth European Working Conditions Survey - Overview report (2017 update). Publications Office of the European Union, Luxembourg.

Eurostat (2018a) Precarious employment by sex, age and NACE Rev. 2 activity.

http://ec.europa.eu/eurostat/web/products-datasets/product?code=Ifsa qoe 4ax1r2.

Eurostat (2018b) Temporary employees by sex, age and main reason.

http://appsso.eurostat.ec.europa.eu/nui/show.do?dataset=lfsa etgar\&lang=en. Accessed 07/06/2018 2018.

Eurostat (2018c) Temporary employess as a percentage of the total number of employees, by sex and age (\%). https://data.europa.eu/euodp/es/data/dataset/aT770QvwY5C6KC3LrPlvA. Accessed 07/05/2018 2018.

Gallie D, Paugam S, Jacobs S (2003) Unemployment, poverty and social isolation: Is there a vicious circle of social exclusion?. European Societies 5(1):1-32.

International Labour Organization (1949) Migration for Employment Convention (Revised) No. 97(Geneva, 32nd ILC session (01 Jul 1949)).

International Labour Organization (1964) Employment Policy Convention No. 122(Geneva, 48th ILC session (09 Jul 1964)).

International Labour Organization (1970) Minimum Wage Fixing Convention No. 131(Geneva, 54th ILC session (22 Jun 1970)).

International Labour Organization (1975) Migrant Workers (Supplementary Provisions) Convention No. 143(Geneva, 60th ILC session (24 Jun 1975)).

International Labour Organization (1983) Vocational Rehabilitation and Employment (Disabled Persons) Convention No. 159(Geneva, 69th ILC session (20 Jun 1983)).

International Labour Organization (1994) Part-Time Work Convention No. 175(Geneva, 81st ILC session (24 Jun 1994)). 
International Labour Organization (1996) Home Work Convention No. 177(Geneva, 83rd ILC session (20 Jun 1996)).

International Labour Organization (1997) Private Employment Agencies Convention No. 181(Geneva, 85th ILC session (19 Jun 1997)).

International Labour Organization (2000) Maternity Protection Convention No. 183(Geneva, 88th ILC session (15 Jun 2000)).

International Labour Organization (2006) Employment Relationship Recommendation No. 198(Geneva, 95th ILC session (15 Jun 2006)).

International Labour Organization (2011a) Domestic Workers Convention No. 189(Geneva, 100th ILC session (16 Jun 2011)).

International Labour Organization (2011b) Policies and regulations to combat precarious employment.

International Labour Organzation (1981) Workers with Family Responsibilities Convention No. 156(Geneva, 67th ILC session (23 Jun 1981)).

Milanovic B (2012) Global inequality recalculated and updated: the effect of new PPP estimates on global inequality and 2005 estimates. Journal of Economic Inequality 10(1):1-18. doi:10.1007/s10888-010-9155-y.

Olsthoorn M (2014) Measuring precarious employment: A proposal for two indicators of precarious employment based on set-theory and tested with Dutch labor market-data. Soc Indicators Res 119(1):421-441.

Stein G (2008) El arte de gobernar según Peter Drucker. Ideas para dirigir en tiempos turbulentos. Gestión 2000, Barcelona.

Stiglitz JE, Sen A, Fitoussi J (2009) The measurement of economic performance and social progress revisited 33 .

The Organisation for Economic Co-operation and Development (OECD) (2018) Temporary employment. https://data.oecd.org/emp/temporary-employment.htm. Accessed 07/06/2018 2018.

United Nations (UN) (2018) Sustainable Development Goals.

https://www.un.org/sustainabledevelopment/sustainable-development-goals/.

Vandekerckhove S, Van Peteghem J, Van Gyes G (2012) Wages and working conditions in the crisis. 